Article

\title{
Long-Term Multilocal Monitoring of Leaf Rust Resistance in the Spring Bread Wheat Genetic Resources from Institute of Plant Genetic Resources (VIR)
}

\author{
Lev Gennadievich Tyryshkin 1,*(D), Yuliya Vital'evna Zeleneva ${ }^{2}$ (D), Alla Nikolaevna Brykova ${ }^{1}$, \\ Evgeniya Yurievna Kudryavtseva ${ }^{1}$, Valentina Alekseevna Loseva ${ }^{3}$, Magomed Alievich Akhmedov ${ }^{4}$, \\ Asef Zilfikarovich Shikhmuradov ${ }^{4}$ and Evgeny Valerievich Zuev ${ }^{1}$
}

Citation: Tyryshkin, L.G.; Zeleneva, Y.V.; Brykova, A.N.; Kudryavtseva, E.Y.; Loseva, V.A.; Akhmedov, M.A. Shikhmuradov, A.Z.; Zuev, E.V. Long-Term Multilocal Monitoring of Leaf Rust Resistance in the Spring Bread Wheat Genetic Resources from Institute of Plant Genetic Resources (VIR). Agronomy 2022, 12, 242. https://doi.org/10.3390/ agronomy 12020242

Academic Editor: Alessio Aprile

Received: 15 December 2021

Accepted: 14 January 2022

Published: 19 January 2022

Publisher's Note: MDPI stays neutral with regard to jurisdictional claims in published maps and institutional affiliations.

Copyright: (C) 2022 by the authors. Licensee MDPI, Basel, Switzerland. This article is an open access article distributed under the terms and conditions of the Creative Commons Attribution (CC BY) license (https:// creativecommons.org/licenses/by/ $4.0 /)$.
1 N.I. Vavilov All-Russian Institute of Plant Genetic Resources, 42, 44 Bolshaya Morskaya Street, 190000 St. Petersburg, Russia; a.brykova@vir.nw.ru (A.N.B.); f-evgenya@rambler.ru (E.Y.K.); e.zuev@vir.nw.ru (E.V.Z.)

2 All-Russian Institute of Plant Protection, Podbel'skogo Street, 3, 196608 St. Petersburg, Russia; zelenewa@mail.ru

3 Yekaterinino Experimental Station, Branch of the N.I. Vavilov Institute of Plant Genetic Resources (VIR), s. Yekaterinino, Nikiforovskii District, 393023 Tambov, Russia; a.mordasowa2014@yandex.ru

4 Dagestan Experimental Station, Branch of the N.I. Vavilov Institute of Plant Genetic Resources (VIR), s. Vavilovo, 368612 Derbent, Russia; makhmed.dos@mail.ru (M.A.A.); asef121263@mail.ru (A.Z.S.)

* Correspondence: tyryshkinlev@rambler.ru

\begin{abstract}
Triticum aestivum L. (bread wheat) is the most important cereal crop in world grain production, including in the territory of the Russian Federation. One of the most important factors influencing the yield and quality of wheat grain is the affection of plants with leaf rust (Puccinia triticina Erikss.). To broaden the set of sources for effective rust resistance, spring bread wheat samples from N.I. Vavilov All-Russian Institute of Plant Genetic Resources (VIR) were monitored for adult resistance to the disease under natural infections for many decades at three distant locations of the Russian Federation: the Dagestan Experimental Station (DES) of VIR (10,549 accessions), Yekaterinino Experimental Station (YES) (4384 accessions), and Pushkin Experimental Field (PEF) (7704 accessions). Information on the disease development at these three stations is presented at least for 51 last years. As a result of disease development evaluation under natural epiphytotic conditions for not less than 3 years, 293 (15 landraces, 127 breeding lines, and 151 commercial varieties), 118 (1 landrace, 38 breeding lines, and 79 commercial varieties), and 127 (10 landraces, 48 breeding lines, and 69 commercial varieties) samples were classified as resistant to leaf rust at DES, YES, and PEF, respectively. Among samples from the State Register of Breeding Achievements in Russia, 15, 13, and 8 spring wheat varieties were resistant to leaf rust at DES, YES, and PEF, respectively. Juvenile resistance was estimated under laboratory conditions after seedling inoculation with a complex population of $P$. triticina: 73 highly resistant varieties and breeding lines were identified; all landraces, including those classified as resistant in the fields, were susceptible to disease at the seedling stage. A total of 26 wheat accessions were identified to be resistant to leaf rust at two to three locations; 14 of them possess adult resistance, and 12 samples have seedling resistance. According to results of PCR amplification with primers specific to markers of effective genes for leaf rust resistance, 6 accessions have gene $L r 9,1$ sample is protected by Lr19, and 1 sample possesses gene $L r 24$. Wheat samples identified as possessing effective seedling or adult resistance could be of interest for breeding in some regions of the Russian Federation and other countries.
\end{abstract}

Keywords: bread wheat; leaf rust; adult resistance; seedling resistance; genes for resistance; long-term multilocal monitoring 


\section{Introduction}

Triticum aestivum L. (bread wheat) is the most important cereal crop in world grain production, including in the territory of the Russian Federation. The area for wheat growing in Russia in 2020 was 28.7 million hectares [1]; the total grain yield of crop this year amounted to 85,896 million tonnes [2].

One of the most important factors influencing the yield and quality of wheat grain is the affection of plants with fungal leaf diseases. One of them is leaf rust (Puccinia triticina Erikss.); it is a harmful disease in all wheat-growing regions. Epiphytoties of the disease are observed every 2-3 years with crop losses in commercial varieties estimated to be at $20-40 \%$ [3]. Despite the development of many methods of controlling rust, it is generally accepted that the best of them, in terms of both economic efficiency and environmental impact, is the cultivation of resistant varieties. The most important step in the creation of such varieties is the search for new sources for effective resistance. Currently, among the varieties of spring wheat allowed for growing in the Russian Federation, there is quite a high frequency of genotypes with juvenile (seedling) and adult resistance to leaf rust, but all of them are protected by an extremely limited number of effective genes [4]. Their extensive use in wheat breeding will lead to their effectiveness loss due to microevolutionary processes in the rust pathogen. As a result, the search for new resistant material is of high interest especially with new effective genes for resistance that has never been used in wheat breeding. The collection of spring bread wheat preserved in N.I. Vavilov All-Russian Institute of Plant Genetic Resources (VIR) (Department of Wheat Genetic Resources) now consists of 15,048 samples from 97 countries. The most represented are accessions from Russia, Mexico, India, Kazakhstan, China, Australia, the USA, Tajikistan, Pakistan, and Turkey. The first specimens were included in the collection as early as in 1907. Most of the samples were introduced in the 1970s. Since 1992, the Russian stage of the collection formation has begun. The up-to-date VIR collection includes landraces, breeding varieties, breeding lines, and genetic lines. Local varieties compose $40 \%$ of the collection, and $60 \%$ of the samples are breeding material. A study on effective resistance to leaf rust in a vast plant gene pool under field and laboratory conditions can lead to the broadening of genetic diversity for a trait in newly developed wheat varieties and hence to the decreasing of yield losses from disease.

The Department of Wheat Genetic Resources has been constantly creating databases for results of field wheat sample evaluations at experimental stations of the institute. Here, we present the results of a long-term leaf rust resistance study on spring wheat samples from the VIR collection at three experimental stations and the results of seedling resistance evaluation in a broad set of crop samples.

\section{Environments, Materials, and Methods}

\subsection{Regions of Wheat Assessment for Leaf Rust Resistance}

Leaf rust development on wheat was assessed at three VIR experimental stations (Figure 1).

The Dagestan Experimental Station (DES) of a VIR branch is located in the Vavilovo village near the town of Derbent (Republic of Dagestan, North Caucasus Region of Russia). The type of soil at the station is light chestnut soil. Spring wheat is grown under irrigation. The climate is transitional from moderate to subtropical semidry. Weather conditions are affected by the Caspian Sea, so autumn is long and warm, and spring comes with a delay. Winter is mild, snow lays only 2 weeks a year. Summer is long and hot. The average annual temperature in Derbent is positive: $+12.5^{\circ} \mathrm{C}$, the average monthly temperature in January is $+1.4^{\circ} \mathrm{C}$, and the average monthly temperature in July is $+24.6^{\circ} \mathrm{C}$. The duration of the warm period is 270 days in a year. The average rainfall quantity is $363 \mathrm{~mm}$ per year; the most rains are in October. The average annual relative humidity is $78.8 \%$. High humidity and temperatures in the range of $+16-22{ }^{\circ} \mathrm{C}$ during May-June (heading-wheat maturation) result in severe leaf rust development in many years [5]. 


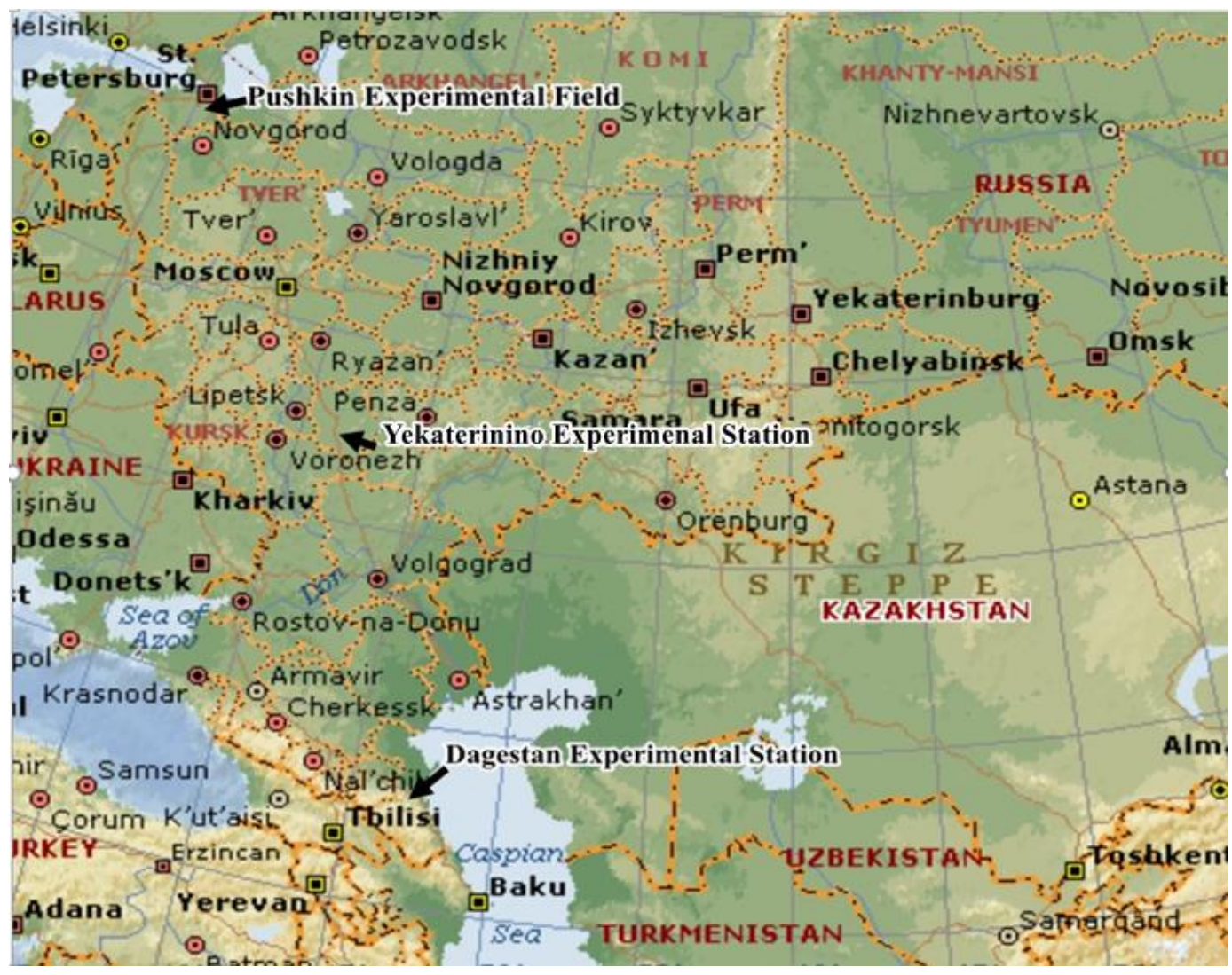

Figure 1. Locations of evaluation experiments of spring wheat germplasm resistance to leaf rust.

The Yekaterinino Experimental Station branch of VIR (YES) is located in the Yekaterinino village (Nikiforovo District, Tambov Region, Central Black Earth Region of Russia). The soils at the station are chernozem. Spring wheat is grown under the absence of artificial irrigation. The climate is moderately continental, with cold and long winters and warm, moderately dry summers. The duration of the period with a temperature above $10{ }^{\circ} \mathrm{C}$ is 145 days, and the temperature sum at this period reaches $2500{ }^{\circ} \mathrm{C}$. The average air temperature is positive $-+4.3^{\circ} \mathrm{C}$. The lowest average monthly temperature in January is $-10.8^{\circ} \mathrm{C}$, and the highest average monthly temperature in July is $+20.0^{\circ} \mathrm{C}$. The average annual precipitation amount is $480-500 \mathrm{~mm}$. The amount of precipitation for the period with an average air temperature above $10^{\circ} \mathrm{C}$ is $230-265 \mathrm{~mm}$. Temperatures in June-July, $+18-20^{\circ} \mathrm{C}$, are optimal for the development of leaf rust, but the moisture deficiency in some years leads to the suppression of pathogen development [6].

The Pushkin Experimental Field (PEF) is a part of the Pushkin and Pavlovsk Laboratories of VIR (Russia, Northwest Region). The soil at the field is podzolic. Wheat is grown under the absence of artificial irrigation. The climate of the Pushkin District of Saint Petersburg is moderate, transitioning from sea to continental. The area is characterized by high humidity and changeable and cloudy weather with moderately cold winters and mild summers. The average air temperature is positive- $+5.2^{\circ} \mathrm{C}$. The lowest average monthly temperature in January is $-5.6^{\circ} \mathrm{C}$, and the highest average monthly temperature in July is $+19.1^{\circ} \mathrm{C}$. During spring wheat heading and maturation (July-August), the average air temperature varies from +17.8 to $16^{\circ} \mathrm{C}$. Precipitation during the growing season is $251 \mathrm{~mm}$. Weather conditions favor the development of leaf rust on wheat crops [7].

\subsection{Plant Material}

The materials of the study were samples of spring bread wheat from the VIR collection; the origin of the samples studied for resistance to leaf rust at three experimental stations of 
the institute is presented in Table 1. The countries of origin of the samples are united in the geographical regions of the world according to methods accepted in VIR [8].

Table 1. Origin of spring wheat samples studied for leaf rust resistance in the VIR system.

\begin{tabular}{cccc}
\hline \multirow{2}{*}{ Region } & \multicolumn{3}{c}{ Number of Samples Evaluated at } \\
\cline { 2 - 4 } & DES & YES & PEF \\
\hline Russia & 1376 & 1217 & 2100 \\
Europe & 1226 & 802 & 1465 \\
Transcaucasia & 326 & 9 & 33 \\
Small Asia and the Middle East & 522 & 43 & 98 \\
Central Asia & 2811 & 683 & 884 \\
Southwest and East Asia & 571 & 112 & 413 \\
Africa & 635 & 129 & 227 \\
North and Central America & 1629 & 636 & 1604 \\
South America & 883 & 524 & 512 \\
Australia and New Zealand & 557 & 219 & 356 \\
Unknown & 13 & - & 12 \\
Total & $\mathbf{1 0 , 5 4 9}$ & 4384 & $\mathbf{7 7 0 4}$ \\
\% Whole collection & 70.1 & 29.1 & 51.2 \\
\hline
\end{tabular}

At the DES, resistance to leaf rust was studied under field conditions in 10,549 samples (70.1\% of the entire collection of spring wheat) from 1962 up to 2020. The largest numbers of entries were from Russia (1376), Mexico (1113), India (692), Australia (545), and Tajikistan (488). Countries such as Mali and Chad were represented with single samples.

At the YES, field evaluation of resistance to rust was conducted in 1970-2020; a total of 4384 varieties and lines (29.1\% of the entire collection) (Table 1$)$ were studied. The largest numbers of samples were from the same countries as in the DES study. Mali and Chad were also presented as single samples.

Field assessment of leaf rust resistance at the PEF was conducted from 1945 till 2020 with 7704 samples of spring wheat $(51.2 \%$ of the entire collection) (Table 1$)$. The largest numbers of samples originated from Russia (2100), Mexico (966), the USA (412), Australia (347), Kazakhstan (346), China (325), Germany (273), and Canada (226). To a lesser extent, the countries of Guatemala, Jordan, Libya, Mali, Mauritania, Paraguay, Syria, and Zimbabwe were represented.

\subsection{Methods}

Field evaluations of resistance were conducted at the natural development of leaf rust using the conventional agricultural technique for spring bread wheat cultivation. The seeding of samples was carried out at the optimal time for a certain region in plots of $1 \mathrm{~m}^{2}$. The standard susceptible varieties were Diamant, Leningradka, Leningradskaya 97 and Leningradskaya 6 (PEF), Siete Cerros (DES), and Kutulukskaya (EOS). Standard varieties were sown after every 20 experimental samples.

The disease ratings were scored twice during the growing season at the heading and milky stages. Classification of a sample for leaf rust resistance was performed according to a 1-9 scale [9-11] (Table 2).

The degree of disease development in a particular year of the study was determined by the average development of leaf rust on standards throughout the field. Disease ratings of 1-3 on standard varieties corresponded to high, and 3-5 to moderate leaf rust development. To identify reliably resistant samples, only data for 3 or more years of high and moderate disease development were taken into analysis. 
Table 2. Scale for field assessment of wheat for leaf rust resistance.

\begin{tabular}{|c|c|c|c|}
\hline $\begin{array}{l}\text { Disease } \\
\text { Rating }\end{array}$ & $\begin{array}{c}\text { Level of } \\
\text { Resistance }\end{array}$ & Pustules & $\begin{array}{c}\text { Leaf Surface } \\
\text { Affected, \% }\end{array}$ \\
\hline 9 & Very high & Single, very small, surrounded with necrosis & $0-5$ \\
\hline 7 & High & Small, sometimes surrounded with chlorosis & $<10$ \\
\hline 5 & Moderate & Small, without or with chlorosis & $\sim 20$ \\
\hline 3 & Low & $\begin{array}{l}\text { Large, sometimes merging, especially } \\
\text { abundant at middle leaves }\end{array}$ & $\sim 50$ \\
\hline 1 & Very low & $\begin{array}{l}\text { Large, dense, merging at middle and } \\
\text { sometimes upper leaves }\end{array}$ & $>50$ \\
\hline
\end{tabular}

A whole set of spring wheat entries to the VIR collection since 2000 was evaluated for seedling (juvenile) resistance to leaf rust. A complex population of P. triticina was created by combining samplings from leaves of several susceptible wheat varieties in the Northwest Region of Russia and North Caucasus and was maintained in the laboratory for seedlings of cv. Leningradka in a light chamber (light 2500 lux, temperature-20-22 ${ }^{\circ} \mathrm{C}$ ). Under these conditions, the population was virulent/avirulent to lines and samples with resistance genes $\operatorname{Lr} 1,2 a, 2 c, 3 b g, 10,11,12,13,14 a, 14 b, 15,16,17,18,20,21,22 a, 22 b, 23$, $25,26,28,29,27+31,32,33,34,35,36,37,38,43,44,45,46,48,49,52,57,60,64 /$ Lr9, 19 , $24,39(=41)$, and 47 . Water suspension of the fungus uredospores $\left(30 \times 10^{3}\right.$ spores $\left./ \mathrm{mL}\right)$ in water was used to infect the experimental material. To study juvenile resistance to the disease, $10-15$ seeds of each sample were placed on cotton wool rolls wetted with water. After 10-15 days, seedlings at the stage of 1-2 leaves were placed in cuvettes horizontally and sprayed with water suspensions of uredospores with the use of a hand atomizer. After inoculation, the cuvettes were wrapped with polyethylene, covered with glass, and placed in the darkness. A day later, the polyethylene film and glass were removed, and seedlings were returned to a vertical position [4].

The types of reaction to $P$. triticina infection were scored on the 12th day after inoculation according to a generally accepted scale [12] with some modifications, where: 0 -no disease symptoms; 0 -necrotic spots without pustules; 1 -very small pustules surrounded by necrosis; 2-medium-sized pustules surrounded by necrosis or chlorosis; 3-large pustules without necrosis; s.p.- single pustules of a susceptible type without necrosis; $X$-pustules of different types on one leaf. Types 0,0 , and 1 correspond to a high level of resistance; 2 , s.p., and X to a moderate level of resistance; and 3 to susceptibility.

Samples resistant to leaf rust in the fields at two to three experimental stations and possessing resistance at seedling stages of ontogenesis were used to identify effective genes for the trait with the use of DNA markers tightly linked to genes Lr9, Lr19, and Lr24. DNA was extracted from three seedlings with a micromethod proposed by Edwards et al. [13] with modifications by Dorokhov and Klocke [14]. The DNA concentration was $50 \mathrm{ng} / \mu \mathrm{L}$. The markers of identified genes are presented in Table 3. Polymerase chain reaction (PCR) was performed in a thermocycler, C-1000 (Bio-Rad, Hercules, CA, USA), according to original protocols [15-17]. Amplification products were electrophoresed on 1.5\% agarose gel in $1 \times$ Tris-boric acid-EDTA (TBE) buffer. 
Table 3. Allele-specific primers of wheat genes for effective leaf rust resistance.

\begin{tabular}{|c|c|c|c|c|}
\hline Gene & Marker & Nucleotide Sequences of Primers & $\begin{array}{c}\text { Size of DNA } \\
\text { Amplification Product, bp }\end{array}$ & Reference \\
\hline Lr9 & SCS5 & $\begin{array}{l}\text { F: 5'-TGC GCC CTT CAA AGG AAG-3' } \\
\text { R: 5'-TGC GCC CTT CTG AAC TGT AT-3' }\end{array}$ & 550 & [15] \\
\hline Lr19 & SCS265 & $\begin{array}{l}\text { F: 5'-GGC GGA TAA GCA GAG CAG AG-3' } \\
\text { R: 5'-GGC GGA TAA GTG GGT TAT GG-3' }\end{array}$ & 512 & [16] \\
\hline Lr24 & $\operatorname{Sr} 24 \neq 12$ & $\begin{array}{c}\text { F: } 5^{\prime}-\text { CAC CCG TGA CAT GCT CGT A-3' } \\
\text { R: } 5^{\prime} \text {-AAC AGG AAA TGA GCA ACG ATG T-3' }\end{array}$ & 500 & [17] \\
\hline
\end{tabular}

\section{Results}

3.1. Resistance of Wheat Samples under the Conditions of the Dagestan Experimental Station of VIR

High and moderate levels of leaf rust development in the field of this station were observed in 41 seasons of spring wheat vegetation out of 59 years of the study (Table 4).

Table 4. Leaf rust development at the Dagestan Experimental Station of VIR.

\begin{tabular}{|c|c|c|c|c|c|c|c|}
\hline Year & $\begin{array}{c}\text { Disease } \\
\text { Development }\end{array}$ & Year & $\begin{array}{c}\text { Disease } \\
\text { Development }\end{array}$ & Year & $\begin{array}{c}\text { Disease } \\
\text { Development }\end{array}$ & Year & $\begin{array}{c}\text { Disease } \\
\text { Development }\end{array}$ \\
\hline 1962 & high & 1977 & high & 1992 & moderate & 2007 & high \\
\hline 1963 & high & 1978 & high & 1993 & moderate & 2008 & high \\
\hline 1964 & high & 1979 & moderate & 1994 & very low & 2009 & very low \\
\hline 1965 & high & 1980 & high & 1995 & moderate & 2010 & very low \\
\hline 1966 & moderate & 1981 & moderate & 1996 & low & 2011 & very low \\
\hline 1967 & moderate & 1982 & moderate & 1997 & low & 2012 & moderate \\
\hline 1968 & high & 1983 & moderate & 1998 & moderate & 2013 & very low \\
\hline 1969 & high & 1984 & high & 1999 & low & 2014 & moderate \\
\hline 1970 & moderate & 1985 & moderate & 2000 & very low & 2015 & very low \\
\hline 1971 & very low & 1986 & moderate & 2001 & high & 2016 & moderate \\
\hline 1972 & very low & 1987 & low & 2002 & very low & 2017 & moderate \\
\hline 1973 & moderate & 1988 & moderate & 2003 & low & 2018 & very low \\
\hline 1974 & high & 1989 & moderate & 2004 & moderate & 2019 & low \\
\hline 1975 & high & 1990 & moderate & 2005 & moderate & 2020 & low \\
\hline 1976 & moderate & 1991 & high & 2006 & moderate & & \\
\hline
\end{tabular}

According to multiannual results, screenings of 34 and 259 samples were highly resistant and resistant to leaf rust, respectively. The greatest number of resistant genotypes originated from the USA (35), Russia (34), Mexico (29), and Australia (25); their distribution among world regions is shown in Figure 2. Highly resistant and resistant samples are represented as landraces and breeding material (Figure 3).

Among landraces, the next samples were classified as resistant to the disease: Stromberg Rooi (k-5717, South Africa), k-11900 (Georgia), A1 (k-28752, China), k-29867 (Argentina), k34482 (Kazakhstan), k-34679 (Kazakhstan), k-36730 (Kazakhstan), Palvan-Bugdai (k-51056, Uzbekistan), k-55839 (Tunisia), k-55844 (Tunisia), k-60211 (Yemen), Local 2427 (k-63081, Egypt), Local 783 (13) (k-63082, Egypt), Local 799 (k-63083, Egypt), k-63085 (Egypt).

The resistant varieties from the State Register of Russian Federation (RF) were Kinel'skaya 60 (k-62643, Samara Region), Altaiskaya 110 (k-65128, Altai Region), Gerkules (k-65129, Omsk Region), Maria 1 (k-65130, Kemerovo Region), Pamyati Vavenkova (k-65132, Novosibirsk Region), Pamyati Aphrodity (to-65135, Kemerovo Region), Svirel (k-65136, Krasnoyarsk Region), Saratovskaya 74 (k-65139, Saratov Region), Raduga (k-65240, Kurgan Region), Tulaikovskaya 100 (k-64643, Samara Region), Kinel'skaya Niva (k-64666, Samara Region), Novosibirskaya 44 (k-64867, Novosibirsk Region), Chelyaba Stepnaya (k-64872, Chelyabinsk Region), Voevoda (k-64997, Saratov Region), and Favorit (k-64998, Saratov region). 


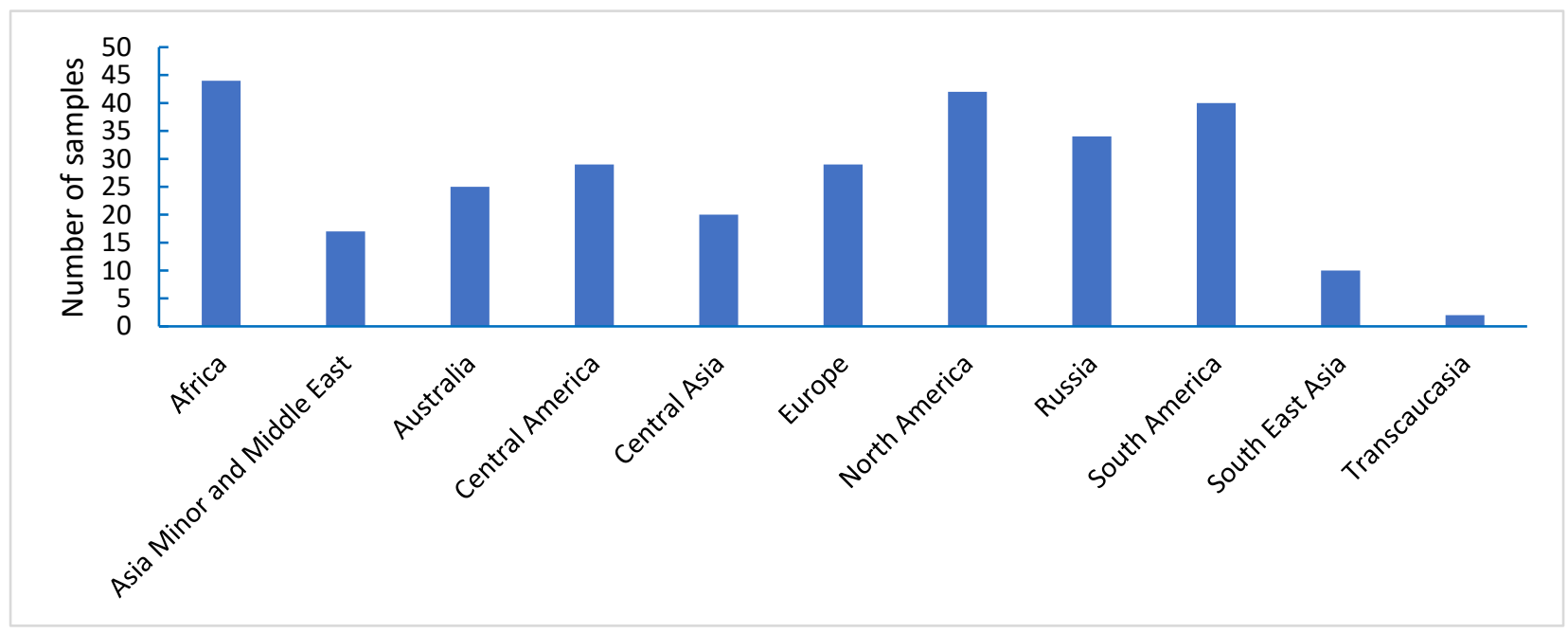

Figure 2. Number of spring bread wheat samples resistant and highly resistant to leaf rust under the conditions of the Dagestan Experimental Station of VIR.

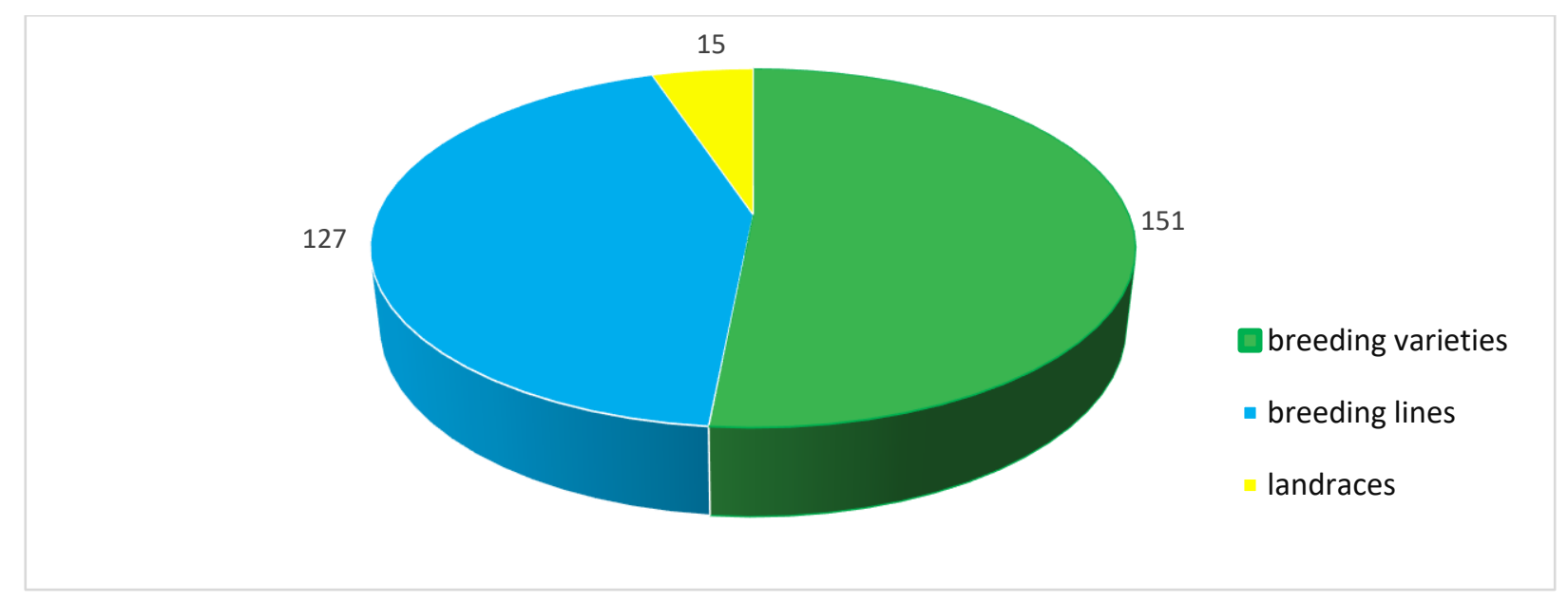

Figure 3. Distribution of spring wheat samples resistant and highly resistant to leaf rust at the Dagestan Experimental Station of VIR for their status.

\subsection{Resistance of Wheat Samples under the Conditions of the Yekaterinino Experimental Station of VIR}

At the YES, wheat leaf rust was observed in high and moderate degrees in 25 and 12 years, respectively, out of 51 when accessions under study were grown. In the last years at this station, disease development was significant annually except in 2015, 2018, and 2019, when rust on bread spring wheat was not recorded (Table 5).

According to the results of the multiyear evaluations, 79 samples were resistant to the disease and 39 samples were highly resistant to rust. The largest numbers of resistant samples originated from Russia (25), Brazil (23), and Mexico (12). The distribution of the identified resistant samples in world regions is presented in Figure 4. Almost all the accessions were represented by breeding material (79 varieties and 38 lines), with the exception of one local variety (landrace) from Yemen-k-58202.

Out of the Russian commercial varieties, L 503 (k-60620, Saratov Region), Duet (k-63500, Chelyabinsk Region), Tulaikovskaya Zolotistaya (k-63715, Samara Region), Aria (k-64545, Kurgan Region), Chelaba Yubileinaya (k-64694, Chelyabinsk Region), and Sibirskii Al'yans (k-65242, Altai Region) were classified as resistant, and Tulaikovskaya 5 (k-62927, Samara Region), Tulaikovskaya 100 (k-64643, Samara Region), Kinel'skaya Niva (k-64666, Samara Region), Novosibirskaya 44 (k-64867, Novosibirsk Region), Stepnaya Chelyaba 
(k-64872, Chelyabinsk Region), Voevoda (k-64997, Saratov Region), and Favorit (k-64998, Saratov Region) were highly resistant to leaf rust.

Table 5. Leaf rust development at the Yekaterinino Experimental Station of VIR.

\begin{tabular}{|c|c|c|c|c|c|c|c|}
\hline Year & $\begin{array}{c}\text { Disease } \\
\text { Development }\end{array}$ & Year & $\begin{array}{c}\text { Disease } \\
\text { Development }\end{array}$ & Year & $\begin{array}{c}\text { Disease } \\
\text { Development }\end{array}$ & Year & $\begin{array}{c}\text { Disease } \\
\text { Development }\end{array}$ \\
\hline 1970 & moderate & 1983 & high & 1996 & low & 2009 & high \\
\hline 1971 & low & 1984 & high & 1997 & moderate & 2010 & low \\
\hline 1972 & low & 1985 & high & 1998 & high & 2011 & high \\
\hline 1973 & low & 1986 & low & 1999 & moderate & 2012 & moderate \\
\hline 1974 & low & 1987 & high & 2000 & moderate & 2013 & high \\
\hline 1975 & high & 1988 & low & 2001 & moderate & 2014 & moderate \\
\hline 1976 & low & 1989 & high & 2002 & moderate & 2015 & low \\
\hline 1977 & moderate & 1990 & high & 2003 & high & 2016 & moderate \\
\hline 1978 & moderate & 1991 & high & 2004 & high & 2017 & high \\
\hline 1979 & low & 1992 & high & 2005 & high & 2018 & low \\
\hline 1980 & high & 1993 & high & 2006 & high & 2019 & low \\
\hline 1981 & low & 1994 & high & 2007 & high & 2020 & moderate \\
\hline 1982 & high & 1995 & high & 2008 & high & & \\
\hline
\end{tabular}

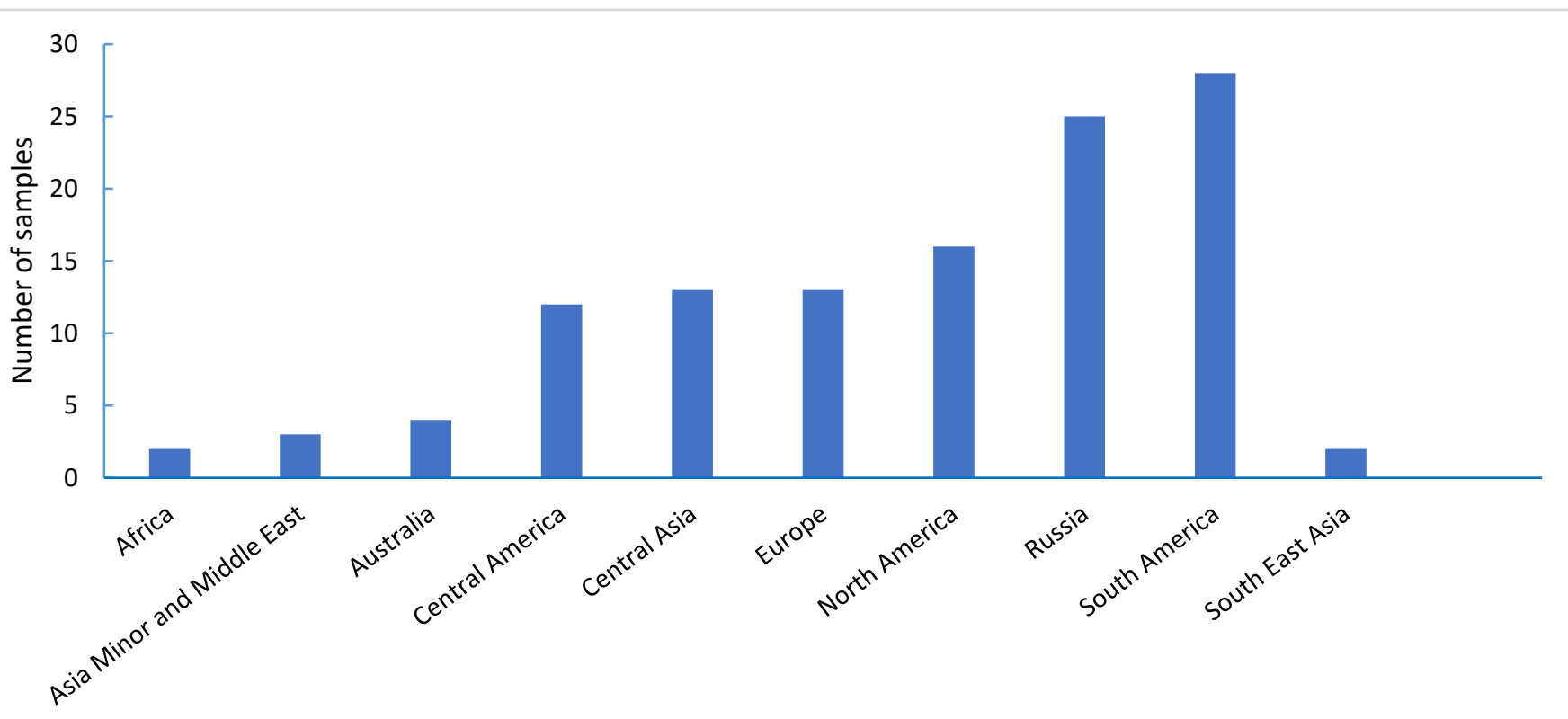

Figure 4. Number of spring bread wheat samples resistant and highly resistant to leaf rust identified at the Yekaterinino Experimental Station of VIR.

\subsection{Resistance of Wheat Samples under the Conditions of the VIR Pushkin Experimental Field}

Under Pushkin town conditions, the development of wheat leaf rust was high and moderate in 12 and 29 years, respectively, out of 51 years under study (Table 6).

According to the results of multiyear evaluations, 90 samples were resistant to the disease and 37 samples were highly resistant. The largest numbers of resistant forms are from the United States (21), Canada (13), Argentina (13), Mexico (10), and Russia (9); the distribution of identified samples in world regions is presented in Figure 5. Resistant and highly resistant accessions were presented by both local varieties and breeding material (Figure 6). 
Table 6. Leaf rust development on wheat at the Pushkin Experimental Field.

\begin{tabular}{|c|c|c|c|c|c|c|c|}
\hline Year & $\begin{array}{l}\text { Development of } \\
\text { the Disease }\end{array}$ & Year & $\begin{array}{l}\text { Development of } \\
\text { the Disease }\end{array}$ & Year & $\begin{array}{l}\text { Development of } \\
\text { the Disease }\end{array}$ & Year & $\begin{array}{l}\text { Development of } \\
\text { the Disease }\end{array}$ \\
\hline 1945 & moderate & 1968 & moderate & 1985 & moderate & 2001 & moderate \\
\hline 1947 & moderate & 1969 & moderate & 1986 & high & 2002 & moderate \\
\hline 1948 & moderate & 1970 & low & 1987 & low & 2004 & low \\
\hline 1951 & moderate & 1971 & moderate & 1988 & moderate & 2006 & low \\
\hline 1957 & high & 1972 & moderate & 1989 & high & 2007 & low \\
\hline 1959 & moderate & 1973 & moderate & 1991 & moderate & 2009 & moderate \\
\hline 1961 & high & 1974 & moderate & 1992 & low & 2010 & high \\
\hline 1962 & moderate & 1975 & low & 1993 & low & 2013 & moderate \\
\hline 1963 & high & 1980 & high & 1994 & moderate & 2014 & high \\
\hline 1964 & high & 1981 & moderate & 1995 & moderate & 2017 & moderate \\
\hline 1965 & moderate & 1982 & moderate & 1996 & low & 2019 & high \\
\hline 1966 & high & 1983 & moderate & 1999 & moderate & 2020 & low \\
\hline 1967 & moderate & 1984 & moderate & 2000 & high & & \\
\hline
\end{tabular}

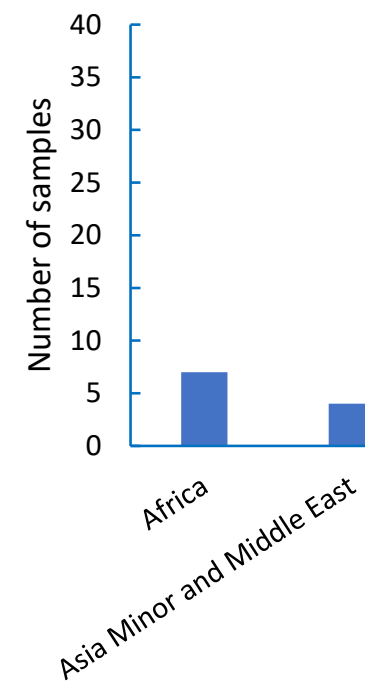

Figure 5. Distribution of wheat samples resistant and highly resistant to leaf rust at the Pushkin Experimental Field.

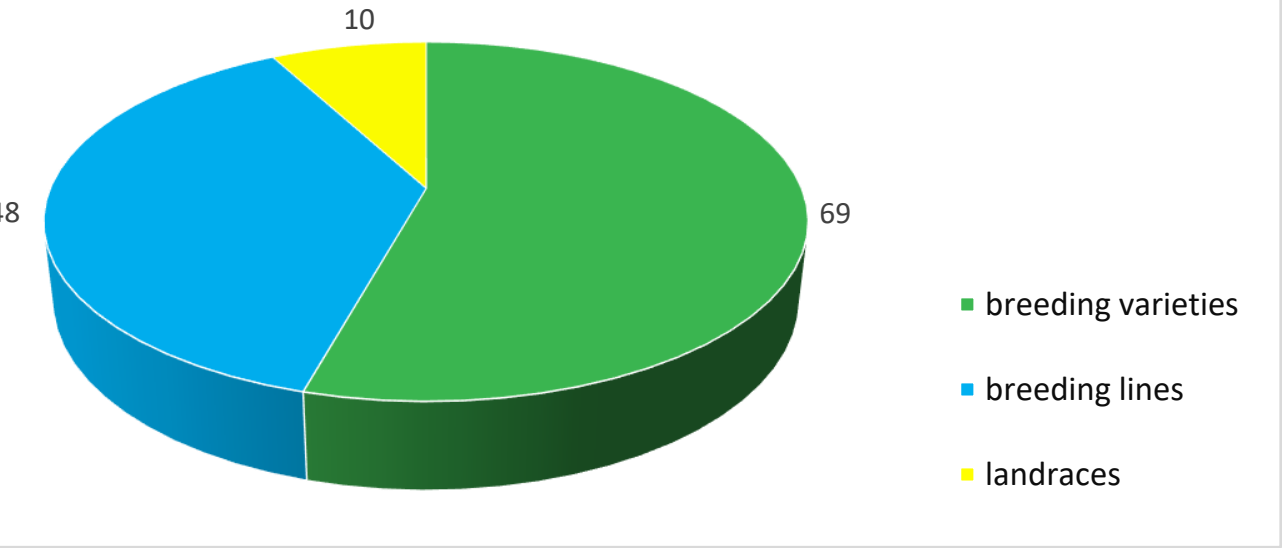

Figure 6. Distribution of spring wheat samples resistant and highly resistant to leaf rust at the Pushkin Experimental Field for their status. 
Among the local samples (landraces) resistant to leaf rust were k-7895 (Russia), 137 (k-28352, China), O1(a) (k-28667, China), Ob(c) (k-28681, China), A1 (k-28752, China), k-29867 (Argentina), k-39538 (Pakistan), Iskamish-K-2-Dark (k-55127, Afghanistan), k-55861 (Portugal), and k-55863 (Portugal).

Varieties from the Russian registry-Kinel'skaya 60 (k-62643, Samara Region), Prokhorovka (k-62644, Saratov Oblast), Tulaikovskaya 10 (k-63714, Samara Region), Tulaikovskaya Zolotistaya (k-63715, Samara Region), Boyevchanka (k-64983, Omsk Region), Kinel'skaya Yubileinaya (k-66270, Samara Region), KWS Torridon (k-66273, United Kingdom), and Arhat (k-66406, Penza Region) — were resistant to leaf rust at this point of the evaluation.

\subsection{Juvenile Resistance of Wheat Samples to Leaf Rust}

In 1999-2020, 3809 samples of spring bread wheat were evaluated for seedling resistance to the disease. A total of 73 highly resistant varieties and breeding lines were identified. Most of these samples were from Russia (Table 7). All landraces, including those classified as resistant in the fields at three experimental stations, were highly susceptible to the disease at the seedling stage.

Due to the fact that juvenile-resistant samples are of greatest interest for breeding purposes, we present a full list of the identified accessions (Table 7).

According to results of molecular marking of 12 samples resistant to leaf rust in the fields at two to three experimental stations and possessing resistance at seedling stages of ontogenesis, gene Lr19 was identified in cultivar Kinel'skaya Niva, Lr24 in cv. Tasman, and gene Lr9 -in samples of Novosibirskaya 44, Chelyaba Stepnaya, Lutescens 30, ANK-4, Olga, and Lubninka (Figures 7-9).

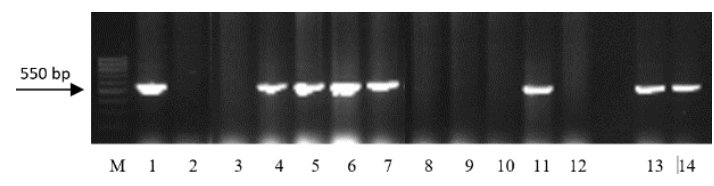

Figure 7. Amplification products after PCR with primers to SCS5, linked to gene Lr9: M-100-bp DNA ladder, 1-ANK-4, 2-LT-1, 3-Favorit, 4-Lubninka, 5-Novosibirskaya 44, 6-Cheliaba Stepnaya, 7-Olga, 8-Tasman, 9-Kinelskaya Niva, 10-Voevoda, 11-Lutescens 30, 12-Tulaikovskaya 100, 13, 14-Thatcher Lr9.

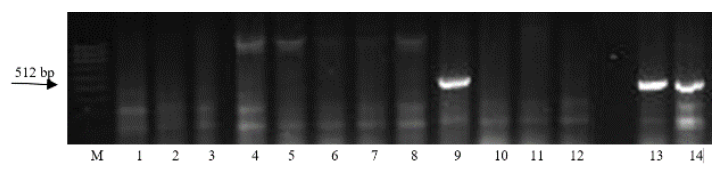

Figure 8. Amplification products after PCR with primers to SCS265, linked to gene Lr19: M-100-bp DNA ladder, 1-ANK-4, 2-LT-1, 3-Favorit, 4-Lubninka, 5-Novosibirskaya 44, 6-Cheliaba Stepnaya, 7-Olga, 8-Tasman, 9-Kinelskaya Niva, 10-Voevoda, 11-Lutescens 30, 12-Tulaikovskaya 100, 13, 14-Thatcher Lr19.

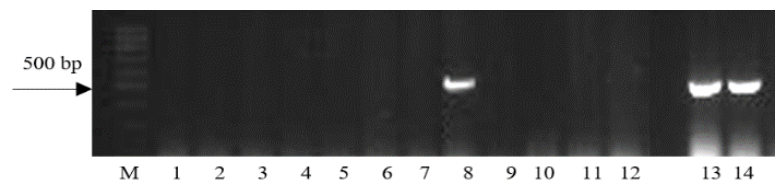

Figure 9. Amplification products after PCR with primers to Sr24 $\neq 12$, linked to gene Lr24: M-100-bp DNA ladder, 1-ANK-4, 2-LT-1, 3-Favorit, 4-Lubninka, 5-Novosibirskaya 44, 6-Cheliaba Stepnaya, 7-Olga, 8-Tasman, 9-Kinelskaya Niva, 10-Voevoda, 11-Lutescens 30, 12-Tulaikovskaya 100, 13, 14-Thatcher Lr24. 
Table 7. Origin of spring wheat samples with effective juvenile resistance to leaf rust.

\begin{tabular}{|c|c|}
\hline Country/Region & Accessions \\
\hline Australia & Skua (k-60613), Tasman (k-63180), Cunningham (k-64209), Sunstate (k-64218) \\
\hline Brazil & $\begin{array}{l}\text { OCEPAR 11-Juriti (k-62612), OCEPAR 8-Macuco (k-62614), BR 31-Miriti (k-62619), } \\
\text { CEP 14-Tapes (k-60944), BR } 34 \text { (k-62185) }\end{array}$ \\
\hline Canada & AC Barrie (k-64596) \\
\hline Mexico & k-65603 \\
\hline Netherlands & Tybalt (k-64897) \\
\hline Poland & Nawra (k-64708) \\
\hline South Africa & SST-23 (k-64138), SST-25 (k-64140) \\
\hline Sweden & WW 17,283 (k-60997) \\
\hline Switzerland & Toronit (k-66032) \\
\hline United Kingdom & Sparrow (k-66090) \\
\hline USA & Stoa (k-59033), Wampum (k-60588), MN 81,330 (k-60785), Russ (k-64595) \\
\hline Unknown & PS 131 (k-64597), PS 133 (k-64598) \\
\hline Russia, Altai & Altaiskaya 65 (k-64455), Altaiskaya 110 (k-65128) \\
\hline Russia, Chelyabinsk & $\begin{array}{c}\text { Quinta (k-63467), Duet (k-63500), Pamiaty Ruba (k-64378), Chelyaba } 2 \text { (to-64379), } \\
\text { Chelyaba } 75 \text { (k-64871), Chelyaba Stepnaya (k-64872) }\end{array}$ \\
\hline Russia, Kemerovo & Tuleevskaya k-63461) \\
\hline Russia, Kurgan & Aria $(\mathrm{k}-64545)$ \\
\hline Russia, Leningrad & LT $1(\mathrm{k}-65816)$ \\
\hline Russia, Novosibirsk & $\begin{array}{c}\text { ANK-4 (k-56395), Obskaya } 14 \text { (k-64363), Udacha (k-64372), Sibirskaya } 24 \text { (k-66442), } \\
\text { Lubninka (k-64866), Novosibirskaya } 44 \text { (k-64867), Olga (k-65000), Novosibirskaya } 18 \\
\text { (k-65820), Sibirskaya } 17 \text { (k-66017), Sibirskaya } 21 \text { (k-66269) }\end{array}$ \\
\hline Russia, Omsk & Lavrusha (k-64984), Omskaya 41 (k-65253), OmGAU 100 (k-66387) \\
\hline Russia, Penza & Yulia (k-63717); \\
\hline Russia, Samara & $\begin{array}{c}\text { Tulaikovskaya } 10 \text { (k-63714), Tulaikovskaya Zolotistaya (k-63715), Tulaikovskaya } 100 \\
\text { (k-64643), Lutescens } 30 \text { (k-64647), Lutescens } 101 \text { (k-64648), Lutescens } 13 \text { (k-64649), } \\
\text { Kinel'skaya Niva (k-64666), Tulaikovskaya } 108 \text { (k-65452), Ekada } 113 \text { (k-65453), } \\
\text { Tulaikovskaya } 110 \text { (k-65454), Tulaikovskaya Nadezhda (k-65827), Kinel'skaya } \\
\text { Yubileinaya (k-66270), Kinel'skaya Volna (k-66274), Tulaikovskaya } 116 \text { (k-66347); }\end{array}$ \\
\hline Russia, Saratov & $\begin{array}{l}\text { L } 505 \text { (k-62892), Dobrynya (k-64252), Voevoda (k-64997), Favorit (k-64998), } \\
\text { Lebedushka (k-66410) }\end{array}$ \\
\hline Russia, Tambov & Mertsana (k-65449) \\
\hline Russia, Tyumen & Latona (k-64359), Tyumenka (k-66271); \\
\hline Russia, Ulyanovsk & Ulyanovskaya 105 (k-66011) \\
\hline Russia, Voronezh & Voronezhskaya 18 (k-65998), Voronezhskaya 20 (k-66257) \\
\hline
\end{tabular}

\section{Discussion}

Wheat leaf rust is one of the widespread and harmful diseases of bread wheat Triticum aestivum L., decreasing the yield and quality of the crop. Despite the development of quite a wide range of methods to protect the crop from the disease, the creation of resistant varieties is considered to be the most profitable and environmentally friendly one. To develop these varieties, the search for sources of new effective genes for resistance remains a very important task. So far, 77 genes for wheat leaf resistance [18,19] have been found, but most of them are ineffective in populations of $P$. triticina from Russia [20,21]. At the juvenile stage, only genes $\operatorname{Lr} 9,19,24,41$, and 47 were highly effective against the pathogen population from the Northwest Region of the Russian Federation [22], but the first three 
of them have already lost their effectiveness in some regions of the country [23-25]. In the past, a large quantity of wheat samples resistant to leaf rust at the adult stage were identified in the world [26-36], but evidently, they cannot be a priori regarded as valuable for breeding in the Russian Federation due to both resistance dependence on the pathogen population structure for virulence and specific for certain region environmental conditions.

The world collection of N.I. Vavilov All-Russian Institute of Plant Genetic Resources (VIR, Russia, Saint Petersburg) is of great interest for the search for valuable breeding material, including wheat for resistance to harmful foliar diseases. It consists of 15,048 accessions of bread spring samples from 97 countries. It presents landraces, breeding, and genetic lines, and varieties.

Systematic field evaluations of wheat VIR collection samples for leaf rust resistance have been initiated since as early as after World War II.

Every year, new entries of wheat accessions from the collection are sent to VIR's experimental stations for 3 years of field studies. The results of the studies are fragmentarily published in editions of the VIR World Collection Catalogues in Russian. The most informative data for leaf rust development evaluation at PEF, DES, and YES were published with 2750, 799, and 228 samples, respectively [37-42]. Data for seedling resistance were published with 1961 samples [43-47].

Due to the variability of phytopathogen populations for virulence and aggressiveness at the same area in different years and the dependence of phenotypical resistance expression on environmental factors, reliable data on resistant sample identification can only be obtained by studying the trait for 3 or more epiphytotic years [48] Therefore, in this paper we classified as resistant only accessions showing scores of 7 and 9 at each station if they were grown during not less than 3 years of high to moderate development of the rust disease.

As a result of long-term multilocal monitoring of leaf rust resistance in spring bread wheat accessions from the VIR collection, we identified 293, 118, and 127 highly resistant and resistant samples under the field conditions of DES, YES, and PEF, respectively. The largest number of resistant accessions was found at DES because the largest set of plant materials was sown there (10,549); it is because the Dagestan Experimental Station was founded by N.I. Vavilov especially for cereal immunological studies, and all entries into the collection were evaluated first of all at this station [49].

Different reasons could be responsible for the noncoincidence of identified resistant samples at three 3 VIR stations. First, up to 2000-year different sets of accessions were evaluated at these stations: at DES, practically all new entries; at PEF, accessions primarily from Northern Europe, Canada, and Asian part of Russia; and at YES, entries from south of European Russia, the USA, and Southern Europe. Second, different years were epiphytotic at different stations, and some samples could not be grown at 3 years of high rust development at a certain place, so they were not referred to as resistant at this station. Third, differences in local rust populations for virulence patterns can explain these results.

Since one of the important tasks of VIR is to collect and preserve commercial Russian varieties, the results emphasized the resistance of the varieties from the Wheat Russian Registry. The State Register of Breeding Achievements in 2020 includes 261 varieties of spring bread wheat [50]. Currently, only 15 varieties are missing in the collection. In total, according to results of three epiphytotic years of evaluation, 15, 13, and 8 varieties (see results) were resistant to leaf rust at DES, YES, and PEF, respectively.

According to a widely accepted viewpoint, local varieties (landraces) are of great interest to identify new sources of effective resistance to fungal diseases in cereals [51-53]. They are supposed to have possibly new genes for resistance not used in modern breeding, and theoretically, they could possess the most valuable durable resistance. Among bread wheat landraces from the VIR collection, resistant samples were identified at DES (15) and PEF (10) (see results).

Juvenile (seedling) resistance to the complex population of $P$. triticina was evaluated in 4500 samples, and 73 were classified as resistant. All local samples were susceptible to the 
disease, so resistant accessions were presented by varieties and breeding lines, varieties from the Russian Federation being the most presented. Most of these identified samples possess known genes for leaf resistance $L r 9$, Lr19, and Lr24 according to phytopathological tests and molecular DNA marking $[4,21,54]$. These genes are widely used in the breeding of spring bread wheat in Russia and abroad, and they have lost their effectiveness in some countries and several parts of Russia [23-25].

Evidently, wheat accessions that have been identified as resistant to leaf rust at two to three locations are of greatest interest for breeding purposes. Their characteristics are presented in Table 8.

Table 8. Samples of spring wheat resistant to leaf rust in fields of two or more locations.

\begin{tabular}{|c|c|c|c|c|c|}
\hline $\begin{array}{c}\text { VIR } \\
\text { Catalogue } \\
\text { Number }\end{array}$ & Variety or Line & Origin & $\begin{array}{c}\text { Resistant at } \\
\text { Experimental } \\
\text { Stations }\end{array}$ & $\begin{array}{l}\text { Types of } \\
\text { Reaction in } \\
\text { Seedlings }\end{array}$ & $\begin{array}{l}\text { Postulated } \\
\text { Effective } L r \\
\text { Genes }\end{array}$ \\
\hline 60980 & $\begin{array}{l}\text { BR 16-Rio } \\
\text { Verde }\end{array}$ & Brazil & YES, PEF & 3 & \\
\hline 61523 & Henika & Poland & YES, PEF & 3 & \\
\hline 62515 & Amidon & USA & YES, DES & 3 & \\
\hline 62552 & HI 977 & India & YES, DES, PEF & 3 & \\
\hline 62874 & Nordic & USA & YES, DES & 3 & \\
\hline 62875 & Norm & USA & YES, DES & 3 & \\
\hline 62878 & AC Minto & Canada & YES, DES & 3 & \\
\hline 62893 & Ranniaya 93 & Ukraine & YES, DES & 3 & \\
\hline 62898 & CDC Teal & Canada & YES, DES & 3 & \\
\hline 63058 & Fjeld & USA & YES, DES & 3 & \\
\hline 63194 & Swift & Australia & YES, DES & 3 & \\
\hline 63215 & Long 82-2124-1 & China & YES, DES & 3 & \\
\hline 64443 & Tepoca & Mexico & YES, PEF & 3 & \\
\hline 64892 & McKenzie & Canada & YES, PEF & 3 & \\
\hline 64643 & $\begin{array}{c}\text { Tulaikovskaya } \\
100\end{array}$ & RF, Samara region & DES, YES & 0 & $\operatorname{Lr} \mathrm{Ag}^{i}{ }^{2}$ * \\
\hline 64647 & Lutescens 30 & RF, Samara region & PEF, YES & 0 & $\operatorname{Lrg}$ \\
\hline 64666 & Kinelskaya Niva & RF, Samara region & DES, YES & 0 & Lr19 \\
\hline 64866 & Lubninka & $\begin{array}{c}\text { RF, Novosibirsk } \\
\text { Region }\end{array}$ & DES, YES & 0 & $\operatorname{Lr} 9$ \\
\hline 64867 & $\begin{array}{c}\text { Novosibirskaya } \\
44\end{array}$ & $\begin{array}{c}\text { RF, Novosibirsk } \\
\text { Region }\end{array}$ & DES, YES & 0 & $\operatorname{Lrg}$ \\
\hline 64872 & $\begin{array}{l}\text { Cheliaba } \\
\text { Stepnaya }\end{array}$ & $\begin{array}{c}\text { RF, Chelyabinsk } \\
\text { Region }\end{array}$ & DES, YES & 0 & $\operatorname{Lrg}$ \\
\hline 64997 & Voevoda & RF, Saratov Region & DES, YES & 0 & $\operatorname{Lr} 6 A g^{i} 1 i^{*}$ \\
\hline 64998 & Favorit & RF, Saratov Region & DES, YES & 0 & $\operatorname{Lr} 6 \mathrm{Ag}^{i} 1^{*}$ \\
\hline 65000 & Olga & $\begin{array}{l}\text { RF, Novosibirsk } \\
\text { Region }\end{array}$ & DES, YES & 0 & $\operatorname{Lrg}$ \\
\hline 56395 & ANK-4 & $\begin{array}{c}\text { RF, Novosibirsk } \\
\text { Region }\end{array}$ & YES, DES, PEF & 0 & $\operatorname{Lrg}$ \\
\hline 63180 & Tasman & Australia & YES, DES, PEF & 0 & $\operatorname{Lr} 24$ \\
\hline 65816 & LT 1 & $\begin{array}{l}\text { RF, Leningrad } \\
\text { region }\end{array}$ & YES, DES, PEF & 0 & \\
\hline
\end{tabular}

*_according to Sibikeev et al., 2017; Guiltiaeva, 2018.

Fourteen accessions possess adult resistance, and 12 samples have seedling resistance. All samples with seedling resistance are with one exception line and varieties from the Russian Federation. According to results of PCR amplification with primers specific to 
markers of effective genes for leaf rust resistance, 6 accessions have gene $\operatorname{Lr} 9$, 1 sample is protected by Lr19, and 1 sample possesses gene Lr24 (Figures 7-9, Table 8). Three varieties, Tulaikovskaya 100, Voevoda, and Favorit, possess genes $\mathrm{Lr}_{6} \mathrm{Ag}^{i} 2$ and $\mathrm{Lr}^{\mathrm{i}} \mathrm{Ag}^{i} 1$ from Agropyron intermedium [21,55], widely used in wheat breeding for rust resistance in the Volga Region of RF. Line LT1 was created at the base of the induction of somaclonal variability in cv. Spica and has genes nonidentical to known effective $L r$ genes.

As a result, wheat samples identified as possessing effective seedling or adult resistance could be of interest for breeding in some regions of the Russian Federation and other countries.

Author Contributions: Conceptualization and methodology, Y.V.Z.; and formal analysis, L.G.T. and E.V.Z.; investigation, L.G.T., Y.V.Z., A.N.B., V.A.L., M.A.A., A.Z.S. and E.V.Z.; resources, E.V.Z., A.N.B. and E.Y.K.; data curation, E.V.Z.; original draft preparation, L.G.T.; writing-review and editing, L.G.T. and E.V.Z.; visualization, L.G.T.; project administration, E.V.Z. All authors have read and agreed to the published version of the manuscript.

Funding: Ministry of Science and Higher Education of the Russian Federation under Agreement No. 075-15-2020-911, 16 November 2020.

Data Availability Statement: Not applicable.

Acknowledgments: The article was made with the support of the Ministry of Science and Higher Education of the Russian Federation under Agreement No. 075-15-2020-911, 16 November 2020, providing a grant in the form of subsidies from the federal budget of the Russian Federation. The grant was provided as state support for the creation and development of a world-class scientific center, "Agro-technologies for the Future".

Conflicts of Interest: The authors declare no conflict of interest.

\section{References}

1. Available online: https://ru.investing.com/news/economy/article-2073183.html (accessed on 7 October 2021).

2. Available online: https://1prime.ru/Agriculture/20210924/834796778.html (accessed on 7 October 2021).

3. Krupnov, V.A. Strategy for genetic protection of wheat from leaf rust in the Volga region. Vestn. Russ. Agric. Sci. 1997, 6, 12-15. (In Russian)

4. Tyryshkin, L.G.; Syukov, V.V.; Zaharov, V.G.; Zuev, E.V.; Gashimov, M.E.; Kolesova, M.A.; Chikida, N.N.; Ershova, M.A.; Belousova, M.H. Sources of effective resistance to fungal diseases in wheat and its relatives-Search, creation and use in breeding. Proc. Appl. Bot. Genet. Breed. 2012, 170, 186-199. (In Russian)

5. Zuev, E.V.; Shikhmuradov, A.Z.; Akhmedov, M.A.; Brykova, A.N.; Kudryavtseva, E.Y. Spring bread wheat. Sources of breeding traits for dagestan conditions. In Catalogue of the VIR World Collection; N.I. Vavilov All-Russian Institute of Plant Genetic Resources: Saint Petersburg, Russia, 2018; Volume 858, pp. 5-7. (In Russian) [CrossRef]

6. Zuev, E.V.; Nikiforov, M.N.; Pankratov, N.N.; Platonov, V.N.; Loseva, V.A.; Brykova, A.N. Spring bread wheat. Sources of breeding traits for TAMBOV region conditions. In Catalogue of the VIR World Collection; N.I. Vavilov All-Russian Institute of Plant Genetic Resources: Saint Petersburg, Russia, 2017; Volume 840, p. 6. (In Russian)

7. Zuev, E.V.; Brykova, A.N.; Kudryavtseva, E.Y. Spring bread wheat. The results of a long-term study of the collection under Leningrad region conditions. In Catalogue of the VIR World Collection; N.I. Vavilov All-Russian Institute of Plant Genetic Resources: Saint Petersburg, Russia, 2020; Volume 917, pp. 5-7. (In Russian) [CrossRef]

8. Zuev, E.V. Spring Bread Wheat Landraces in the VIR World Collection; N.I. Vavilov All-Russian Institute of Plant Genetic Resources: Saint Petersburg, Russia, 2008; pp. 1-161. (In Russian)

9. Rudenko, M.I.; Shitova, I.P.; Korneichuk, V.A. Guidelines to Study the World Wheat Collection; N.I. Vavilov All-Russian Institute of Plant Industry: Saint Petersburg, Russia, 1977; pp. 1-28. (In Russian)

10. Gradchaninova, O.D.; Filatenko, A.A.; Rudenko, M.I. The Study of the Wheat Collection: Guidelines; N.I. Vavilov All-Russian Institute of Plant Industry: Saint Petersburg, Russia, 1985; pp. 1-27. (In Russian)

11. Merezhko, A.F.; Udachin, R.A.; Zuev, E.V.; Filatenko, A.A.; Serbin, A.A.; Lyapunova, O.F.; Kosov, V.Y.; Kurkiev, U.K.; Okhotnikova, T.V.; Navruzbekov, N.A.; et al. Introduction, Conservation, and Study of the World Collection of Wheat, Aegilops and Triticale. Guidelines; N.I. Vavilov All-Russian Institute of Plant Industry: Saint Petersburg, Russia, 1999; pp. 1-81. (In Russian)

12. Mains, E.B.; Jackson, H.S. Physiological specialization in leaf rust of wheat Puccinia triticina Erikss. Phytopathology 1926, 16, 89-120.

13. Edwards, K.; Johnstone, C.; Thompson, C. A simple and rapid method for the preparation of plant genomic DNA for PCR analysis. Nucl. Acids Res. 1991, 19, 1349. [CrossRef] [PubMed] 
14. Dorokhov, D.B.; Klocke, E. A rapid and economic technique for RAPD-analysis of plant genomes. Russ. J. Genet. 1997, 33, 443-450. (In Russian)

15. Gupta, S.K.; Charpe, A.; Koul, S.; Prabhu, K.V.; Haq, Q.M.R. Development and validation of molecular markers linked to an Aegilops umbellulata-derived leaf rust-resistance gene, Lr9, for marker-assisted selection in bread wheat. Genome 2005, 48, 823-830. [CrossRef]

16. Gupta, S.K.; Charpe, A.; Prabhu, K.W.; Haque, O.M.R. Identification and validation of molecular markers linked to the leaf rust resistance gene Lr19 in wheat. Theor. Appl. Genet. 2006, 113, 1027-1036. [CrossRef]

17. Mago, R.; Bariana, H.S.; Dundas, I.S.; Spielmeyer, W.; Lawrence, G.J.; Pryor, A.J.; Ellis, J.G. Development or PCR markers for the selection of wheat stem rust resistance genes Sr24 and Sr26 in diverse wheat germplasm. Theor. Appl. Genet. 2005, 111, 496-504. [CrossRef]

18. McIntosh, R.A.; Yamazaki, Y.; Dubcovsky, J.; Rogers, J.; Morris, C.; Appels, R.; Xia, X.C. Catalogue of Gene Symbols for Wheat. 2013. Available online: https://shigen.nig.ac.jp/wheat/komugi/genes/macgene/2013/GeneSymbol.pdf (accessed on 3 September 2020).

19. McIntosh, R.A.; Dubcovsky, J.; Rogers, W.J.; Morris, C.; Xia, X.C. Catalogue of Gene Symbols for Wheat: 2017 Supplement. Available online: https:/ / shigen.nig.ac.jp/wheat/komugi/genes/macgene/supplement2017.pdf (accessed on 7 December 2020).

20. Tyryshkin, L.G. Genetic Diversity of Wheat and Barley for Effective Diseases Resistance and the Possibility of Its Broadening Doctoral Dissertation, N.I. Vavilov All-Russian Institute of Plant Industry, Saint Petersburg, Russia, 2007; pp. 1-254. (In Russian)

21. Guiltiaeva, E.I. Genetic Structure of Puccinia triticina Populations in Russia and Its Variation under the Influence of Host Plants. Ph.D. Thesis, All-Russian Institute of Plant Protection, Saint Petersburg, Russia, 2018. (In Russian)

22. Tyryshkin, L.G.; Volkova, G.V.; Kolomiets, T.M.; Brykova, A.N.; Zuev, E.V. Effective resistance to leaf rust in spring bread wheat accessions from new entries of VIR collection. Vavilovia 2019, 2, 35-43. (In Russian) [CrossRef]

23. Vyuskov, A.A. Breeding of Spring Bread Wheat for Resistance to Leaf Rust in the Middle Volga Region. Ph.D. Thesis, N.I. Vavilov All-Russian Institute of Plant Industry, Saint Petersburg, Russia, 1988. (In Russian)

24. Markelova, T.S. Study of the structure and variability of the wheat brown rust population in the Volga region. Agro XXI 2007, 4-6, 37-40. (In Russian)

25. Meshkova, L.V.; Rosseeva, L.P.; Shreider, E.R.; Sidorov, A.V. Virulence of pathotypes of wheat leaf rust to TH Lr9 in the regions of Siberia and the Ural. In Proceedings of the II All-Russian Conference "Modern Problems of Plant Immunity to Harmful Organisms", Saint Petersburg, Russia, 29 September-2 October 2008; pp. 70-73. (In Russian)

26. Sayre, K.; Singh, R.P.; Huerta-Espino, J.; Rajaram, S. Genetic progress in reducing losses to leaf rust in CIMMYT derived Mexican spring wheat varieties. Crop. Sci. 1998, 38, 654-659. [CrossRef]

27. Singh, R.P.; Huerta-Espino, J.; William, H.M. Genetics and breeding for durable resistance to leaf and stripe rusts in wheat. Turk. J. Agric. For. 2005, 29, 121-127.

28. Pathan, A.K.; Park, R.F. Evaluation of seedling and adult plant resistance to leaf rust in European wheat varieties. Euphytica 2006, 149, 327-342. [CrossRef]

29. Hovmoller, M.S. Sources of seedling and adult plant resistance to Puccinia striiformis f.sp. tritici in European wheats. Plant Breed. 2007, 126, 225-233. [CrossRef]

30. Li, Z.F.; Xia, X.C.; He, Z.H.; Li, X.; Zhang, L.J.; Wang, H.Y.; Meng, Q.F.; Yang, W.X.; Li, G.Q.; Liu, D.Q. Seedling and slow rusting resistance to leaf rust in Chinese wheat varieties. Plant Dis. 2010, 94, 45-53. [CrossRef]

31. Sun, Y.; Hu, Y.Y.; Yang, W.X.; Liu, D.Q. Evaluation of the resistance to leaf rust of 6 wheat lines. J. Triticeae Crops 2011, 31, 762-768.

32. Vanzetti, L.S.; Campos, P.; Demichelis, M.; Lombardo, L.A.; Aurelia, P.R.; Vaschetto, L.M.; Bainotti, C.T.; Helguera, M. Identification of leaf rust resistance genes in selected Argentinean bread wheat varieties by gene postulation and molecular markers. Electron. J. Biotechnol. 2011, 14, 3. [CrossRef]

33. Azzimonti, G.; Lannou, C.; Sache, I.; Goyeau, H. Components of quantitative resistance to leaf rust in wheat varieties: Diversity, variability and specificity. Plant Pathol. 2013, 62, 970-981. [CrossRef]

34. Dakouri, A.; McCallum, B.D.; Radovanovic, N.; Cloutier, S. Molecular and phenotypic characterization of seedling and adult plant leaf rust resistance in a world wheat collection. Mol. Breed. 2013, 32, 663-677. [CrossRef] [PubMed]

35. Draz, I.S.; Abou-Elseoud, M.S.; Kamara, A.M.; Alaa-Eldein, O.A.; El-Bebany, A.F. Screening of wheat genotypes for leaf rust resistance along with grain yield. Ann. Agric. Sci. 2015, 60, 29-39. [CrossRef]

36. Li, J.; Shi, L.; Wang, X.; Zhang, N.; Wei, X.; Zhang, L.; Yang, W.; Liu, D. Leaf rust resistance of 35 wheat varieties (lines). J. Plant Pathol. Microbiol. 2018, 9, 429. [CrossRef]

37. Bershtein, E.M. Wheats of Australia. In Catalogue of the VIR World Collection; N.I. Vavilov All-Russian Institute of Plant Industry: Saint Petersburg, Russia, 1969; Volume 52, pp. 1-23. (In Russian)

38. Yakubtsiner, M.M.; Krivchenko, V.I.; Myagkova, D.V.; Grigor'eva, O.G.; Trainina, S.I. Catalogue of Spring Wheat Accessions with Characteristics for Their Resistance to Leaf and Stem Rusts, Common Bunt, Loose Smut and Powdery Mildew; N.I. Vavilov All-Russian Institute of Plant Industry: Saint Petersburg, Russia, 1973; Volume 124, pp. 1-37. (In Russian)

39. Myagkova, D.V.; Grigor'eva, O.G.; Vershinina, V.A.; Krivchenko, V.I.; Udachin, R.A.; Kudryavtseva, Z.V. Spring wheat accessions with characteristics for their resistance to leaf and stem rusts, common bunt, loose smut and powdery mildew. In Catalogue of the VIR World Collection; N.I. Vavilov All-Russian Institute of Plant Industry: Saint Petersburg, Russia, 1981; Volume 304, pp. 1-79. (In Russian) 
40. Udachin, R.A.; Myagkova, D.V.; Surganova, L.D.; Semenova, L.V. Spring bread wheat. Immunological and agrobiological evaluation of accessions under the conditions of the Non-Chernozem Zone of the RSFSR. In Catalogue of the VIR World Collection; N.I. Vavilov All-Russian Institute of Plant Industry: Saint Petersburg, Russia, 1990; Volume 567, pp. 1-38. (In Russian)

41. Surganova, L.D.; Semenova, L.V.; Kuznetsova, O.I.; Naumova, V.I.; Brykova, A.N.; Lyapunova, O.A.; Starikova, I.A. Spring bread wheat. Agrobiological evaluation of accessions under the conditions of the Non-Chernozem Zone of Russia. In Catalogue of the VIR World Collection; N.I. Vavilov All-Russian Institute of Plant Industry: Saint Petersburg, Russia, 1992; Volume 623, pp. 1-35. (In Russian)

42. Khakimova, A.G.; Zuev, E.V.; Brykova, A.N.; Klement'eva, N.F.; Chmeleva, Z.V.; Nikiforov, M.N. Complex evaluation of perspective spring bread wheat accessions for grain quality in the Central Chernozem region of Russia. In Catalogue of the VIR World Collection; N.I. Vavilov All-Russian Institute of Plant Industry: Saint Petersburg, Russia, 1999; Volume 698, pp. 1-47. (In Russian)

43. Tyryshkin, L.G.; Lebedeva, T.V.; Zuev, E.V.; Loskutova, N.P.; Brykova, A.N.; Pyukkenen, V.P. Characterization of bread wheat accessions for resistance to obligate and facultative fungal pathogens. In Catalogue of the VIR World Collection; N.I. Vavilov All-Russian Institute of Plant Industry: Saint Petersburg, Russia, 2000; Volume 718, pp. 1-24. (In Russian)

44. Tyryshkin, L.G.; Tyryshkina, N.A.; Zuev, E.V.; Brykova, A.N.; Kovaleva, M.M.; Ershova, M.A. Spring bread wheat. Characteristics of new VIR's accessions for resistance to fungal diseases. In Catalogue of the VIR World Collection; N.I. Vavilov All-Russian Institute of Plant Industry: Saint Petersburg, Russia, 2004; Volume 749, pp. 1-19. (In Russian)

45. Tyryshkin, L.G.; Lebedeva, T.V.; Kovaleva, M.M.; Zuev, E.V.; Brykova, A.N.; Stetsyuk, S.N. Spring bread wheat. Characteristics of new VIR's accessions for resistance to leaf rust, dark-brown leaf spot blotch, Septoria nodorum blotch, powdery mildew, and scab. In Catalogue of the VIR World Collection; N.I. Vavilov All-Russian Institute of Plant Industry: Saint Petersburg, Russia, 2009; Volume 795, pp. 1-20. (In Russian)

46. Tyryshkin, L.G.; Lebedeva, T.V.; Kovaleva, M.M.; Zuev, E.V.; Brykova, A.N.; Stetsyuk, S.N. Spring bread wheat. Characteristics of new VIR's accessions for resistance to leaf rust, dark-brown leaf spot blotch, powdery mildew, and scab. In Catalogue of the VIR World Collection; N.I. Vavilov All-Russian Institute of Plant Genetic Resources: Saint Petersburg, Russia, 2015; Volume 823, pp. 1-19. (In Russian)

47. Tyryshkin, L.G.; Lebedeva, T.V.; Kovaleva, M.M.; Zuev, E.V.; Brykova, A.N.; Kudryavtseva, E.Y. Spring bread wheat. Characteristics of new VIR's accessions for resistance to leaf rust, dark-brown leaf spot blotch, powdery mildew and loose smut. In Catalogue of the VIR World Collection; N.I. Vavilov All-Russian Institute of Plant Genetic Resources: Saint Petersburg, Russia, 2020; Volume 913, pp. 1-23. (In Russian) [CrossRef]

48. Kurbanova, P.M. Genetic Diversity of Spring Bread Wheat for Effective Adult Resistance to Leaf Rust. Ph.D. Thesis, N.I. Vavilov All-Russian Institute of Plant Genetic Resources, Saint Petersburg, Russia, 2009. (In Russian)

49. Alderov, A.A. Theoretical and Applied Aspects of the Genus Triticum L. Genetic Resources Study in Dagestan; N.I. Vavilov All-Russian Institute of Plant Industry: Saint Petersburg, Russia, 2005; pp. 3-7. (In Russian)

50. Official Website of Gossort Russia. Available online: http://gossortrf.ru (accessed on 15 November 2020).

51. Vavilov, N.I. The Theory of Immunity of Plants to Infectious Diseases. The Theoretical Basis of Plant Breeding; Lenselkhozgis: MoscowLeningrad, Russia, 1935; Volume 1, pp. 893-990. (In Russian)

52. Czembor, J.H.; Czembor, H.J.; Attene, G.; Papa, R. Leaf rust resistance in selections from barley landraces collected in Sardinia. Plant Breed. Seed Sci. 2007, 56, 73-84.

53. Abdullaev, R.A.; Lebedeva, T.V.; Alpatieva, N.V.; Yakovleva, O.V.; Kovaleva, O.N.; Radchenko, E.E.; Anisimova, I.N.; Batasheva, B.A.; Karabitsina, Y.I.; Kuznetsova, E.B. Genetic Diversity of Barley Accessions from Ethiopia for Powdery Mildew Resistance. Russ. Agric. Sci. 2019, 45, 232-235. [CrossRef]

54. Tyryshkin, L.G. Genetic control of effective juvenile resistance to leaf rust in collection samples of Triticum aestivum L. Russ. J. Genet. 2006, 42, 294-300. [CrossRef]

55. Sibikeev, S.N.; Badaeva, E.D.; Gultyaeva, E.I.; Druzhin, A.E.; Shishkina, A.A.; Dragovich, A.Y.; Kroupin, P.Y.; Karlov, G.I.; Khuat, T.M.; Divashuk, M.G. Comparative analysis of Agropyron intermedium (Host) Beauv 6Agi and 6Agi2 chromosomes in bread wheat varieties and lines with wheat-wheatgrass substitutions. Russ. J. Genet. 2017, 53, 298-309. [CrossRef] 